\title{
ANALYSIS OF DIFFERENCES BETWEEN MALE AND FEMALE STUDENTS IN THE EAT26 EATING HABITS ASSESSMENT TEST
}

\author{
Ivana Cosić Mulahasanović1, Amra Nožinović Mujanović², Edin Mujanović, ${ }^{2}$ Alem Šabović3 ${ }^{3}$ Ivan Ledić3, \\ Anđelko Šimićs \\ 1 E.S. "Maglaj", Maglaj, Bosnia and Herzegovina \\ ${ }^{2}$ Faculty of Physical Education and Sport, University of Tuzla, Bosnia and Herzegovina \\ ${ }^{1} \mathrm{PhD}$ student in kinesiology
}

Original scientific paper

\begin{abstract}
The paper emphasizes that the period of beginning study is alarming, because through the new life circumstances, obligations and environment, great changes occur and a personal hierarchy of values and priorities of students in their lives is formed. The aim of the research was to determine eating habits and differences in relation to gender among students at the University of Tuzla. The research was conducted on a sample of 813 respondents, male and female students of the University of Tuzla. Eating attitude test (EAT26) is used for diagnosis of eating habits. Obtained results sowed statistically significant difference between male and female students in the applied test EAT26.
\end{abstract}

Key words: EAT26, eating habits, students

\section{INTRODUCTION}

Nutrition is of great importance for all ages. Eating habits are formed from the first days of the transition from breast milk to solid food, and the better we adopt eating habits, the greater the possibility for the prevention of diseases such as obesity, cardiovascular diseases, etc. During their studies, most young people encounter independence for the first time, leaving home for a new environment, and creating new habits. All these changes in the environment affect the student, and lead to changes in life and health habits. Students do almost no physical activity and focus more and more on a passive lifestyle. Due to the lack of time and obligations at the faculty, they are increasingly consuming food of high energy value, and less and less "healthy food". Students' eating habits get worse with age, factors that put students at risk are financial problems, skipping meals, lack of dietary diversity and frequent consumption of fast food. (Driskell et al., 2005). The problem of overweight shows that not only risk factors such as insufficient physical activity and improper diet are what affect the body mass index but also that young people in adolescence experience unrealistic in relation to the objective situation of their nutrition. This makes them vulnerable and affects the experience of themselves, as well as the assessment of satisfaction with their own lives.

Adolescence is considered a critical period for the development of eating disorders. The data show that as many as $40-70 \%$ of adolescent girls are dissatisfied with some aspects of their body, have extremely negative feelings towards them and want to be thinner. Research shows that as many as $50.4 \%$ of surveyed girls follow a diet
(Rukavina, 2002), and $49.6 \%$ of them believe that their ideal weight is lower than the current one by an average of 3 to 4 kilograms (Gladović, 1999).

According to Trivunčić (1998), as many as $80 \%$ of girls are dissatisfied with the appearance of their own bodies and show a desire to lose weight. This is the reason why girls start a diet, and following a diet increases the likelihood of eating disorders by eight times (Dalle Grave \& De Luca, 1999).

\section{METHODS \\ Participants}

The research was conducted on a sample of 813 respondents, male and female students of the University of Tuzla. The university has 13 faculties, of which 11 are included in this research. The research was conducted in the academic year 2015/2016 in the summer semester.

\section{Sample variables}

Eating attitude test (EAT26) is the most commonly used standardized measurement of symptoms and characteristics of eating habits. (Garner, Olmsted, Bohr \& Garfinkel, 1982). The 26 -item version is very reliable and valid (Garner, Olmsted, Bohr \& Garfinkel, 1982; Lee et al., 2002; Mintz \& O'Halloran, 2000).

EAT-26 alone does not provide a specific diagnosis of eating habits (neither EAT-26 nor any other screening instrument has been established to be highly effective in self-identifying eating disorders), however, it is a particularly useful tool for assessing the "risk of eating disorders" in high 
school, college, and other special samples such as athletes (Garner, Rosen \& Barry, 1998). The examination for eating habits is based on the assumption that early identification of eating disorders can lead to early treatment, thus reducing serious physical and psychological complications or even death.

This test is based on the Likert scale $(0=$ never, almost never or occasionally; 1 = sometimes; 2 = often; 3 = always) of a self-applicable questionnaire, which has 26 statements, and where the result of the statement on 25 statements are viewed in reverse.

1) Diet - indicates a pathological rejection of foods with high energy value and concerns about physical appearance;

2) Bulimia and nutrition preoccupation - indicates the induction of the urge to vomit to lose or control body weight;

3) Oral self-control - reflects self-control over food and assessment of the environment and the strength of the society that encourages eating. The results of the subscales are obtained by summing all the items assigned to that particular scale:

Diet Scale Items: 1, 6, 7, 10, 11, 12, 14, 16, 17, 22, 23, 24, 26.

Bulimia and nutrition preoccupation Scale Items: 3, 4, 9, 18, 21, 25.

Oral self-control scale items: $2,5,8,13,15,19$, 20.

Table 1. Results of the Mann-Whitney $U$ test between male and female students in the test for assessing eating habits

\begin{tabular}{cccc}
\hline & $\begin{array}{c}\text { Male student1/ } \\
\text { Female student2 }\end{array}$ & Mean Rank & p-value \\
\hline \multirow{2}{*}{ EAT26 } & 1 & 369.84 & .000 \\
DIET & 2 & 430.46 & \\
BULIMIA & 1 & 397.94 & .396 \\
& 2 & 412.10 & .000 \\
ORAL CONTROL & 1 & 369.12 & .001 \\
\hline
\end{tabular}

Table 2. Frequency of results in female students

\begin{tabular}{|c|c|c|c|c|c|}
\hline \multicolumn{2}{|c|}{ EAT 26 score } & $\mathrm{N}$ & Percent & Mean & Std. Deviation \\
\hline \multirow{3}{*}{ Valid } & Normal $<20$ & 412 & 83.7 & 10.45 & 4.218 \\
\hline & $\begin{array}{c}\text { Abnormal } \geq \\
20\end{array}$ & 80 & 16.3 & 25.40 & 5.888 \\
\hline & Total & 492 & 100.0 & 12.88 & 7.140 \\
\hline
\end{tabular}

\section{Statistical data processing}

A nonparametric Mann-Whitney test for independent samples will be used to determine differences in dietary habits (EAT26) between groups of subjects classified by gender.

\section{RESULTS AND DISCUSSION}

Review of Mann-Whitney $U$ results in the test for variables for assessing eating habits shown in Table 1, we see that there is a statistically significant difference between male and female students in the applied variables EAT26, BULIMIA and ORAL CONTROL at the level of statistical significance $p<.01$. By reviewing the results of the mean values of the ranks (Mean Rank), we notice that the students compared to the female students achieved lower values expressed in these variables.

The results obtained for female students of the University of Tuzla indicate that $83.7 \%$ of them belong to the group of people with normal eating habits, but $16.3 \%$ of them indicate possible eating disorders such as diet, bulimia and oral control. The obtained results also indicate that $91 \%$ of male students at the University of Tuzla belong to the group of people with normal eating habits, and that $9 \%$ of them belong to the group with possible eating disorders. 
Table 3. Frequency of male student results

\begin{tabular}{cccccc}
\hline \multicolumn{2}{c}{ EAT 26 score } & N & Percent & Mean & Std. Deviation \\
\hline \multirow{3}{*}{ Valid } & Normal $<20$ & 292 & 91.0 & 9.74 & 4.647 \\
\cline { 2 - 6 } & $\begin{array}{c}\text { Abnormal } \geq \\
20\end{array}$ & 29 & 9.0 & 24.93 & 4.079 \\
\cline { 2 - 6 } & Total & 321 & 100.0 & 11.11 & 6.334 \\
\hline
\end{tabular}

The analysis of the obtained results shows that a larger number of men than women belong to the group of people with normal eating habits, while the number of girls who belong to the group of people with possible eating disorders is almost twice as high as men.

The statistically significant difference between the sexes is only not confirmed in the variable DIET, although the analysis shows a slightly higher mean value obtained among female students. Many studies have found gender differences, more precisely, that women are more prone to eating disorders than men (Cox, Lantz \& Mayhew, 1997; Nelson, Hughes, Katz \& Searight, 1999; Stephens at al., 1999). The prevalence of anorexia and bulimia in girls has been reported in Western countries (Makino, Tsuboi \& Dennerstein, 2004). Eating disorders are psychological illnesses with abnormal eating habits, more common in women around the age of 25. (Deering, 2001), however, studies further state that eating disorders are increasingly occurring in young men as well (Sepulveda et al., 2008; Lavender et al., 2010). Abnormal eating behaviors, unhealthy weight control methods, and eating disorders are symptoms increasingly present in university students (White et al., 2011; Eisenberg et al., 2011). The most common risk factors for the development of eating disorders are biological, psychological and environmental factors (Schmidt, 2003). After graduating from high school in the transition period to college, the presence of a new environment with multiple aspects of looking, affects young people of both sexes in different ways (Vohs et al., 2001).

In a study (Smith, 2005) on a sample of American students, the results indicate that of the total number of male and female students, $84 \%$ belonged to the group of normal eating habits, whose scores indicated a normal EAT26 score, ie results were less than 20 , while the group with abnormal eating habits consisted of $16 \%$ of them. They also state that girls were the ones who for the most part achieved higher results than men, and that girls were more prone to eating disorders than men.In a study (Hoerr et al.,
2002) on a sample of students, their results also indicate that $10.9 \%$ of girls and $4.0 \%$ of men had a total EAT26 score equal to or higher than 20 $(\geq 20)$.

However, there are studies that indicate differences in eating habits in women in relation to the achieved higher and lower levels of physical activity. (Lepage \& Crowther, 2010).

Young adults, especially during the transition period, by moving to college, become prone to eating disorders, when parents have little control over them or influence their eating habits. (Morris, Parra \& Stender, 2011).

The diet is obviously something common to students that both men and girls at the University of Tuzla reach for equally. Most often, given the body weight and satisfaction with physical appearance, they opt for reduction and innovation through eating habits, we consider it possible from previous studies that indicate a positive association BMI i EAT-26.

\section{CONCLUSION}

It is during the period of study that young people usually face independence for the first time and create their own life, including eating habits. The results obtained on the eating habits of students in this study record deviations from the recommendations for a healthy lifestyle, and for these reasons it is desirable to organize various workshops and lectures on proper nutrition to educate students about proper nutrition according to their needs. Through numerous studies conducted worldwide on the student population as well as in this study, it has been observed that some behaviors in this population are consistently repeated.

Poor eating and health habits, such as lack of physical activity and smoking, result in an increasing number of young people who have weight problems, so it is important to make students aware of the importance of a balanced diet as well as physical activity. 


\section{REFERENCES}

1. Cox, L.M., Lantz, C.D., Mayhew, J.L. (1997). The role of social physique anxiety and other variables in predicting eating behaviors in college students. Int J Sport Nutr. Dec;7(4):310-7.

2. Dalle Grave, R., De Luca, L. (1999). Prevenzione dei disturbi dell'alimentazione. Un programma di educazione e prevenzione primaria e secondaria per operatori socio-sanitari. Verona: Positive Press.

3. Deering, S. (2001). Eating disorders: recognition, evaluation and implications for obstetrician/gynecologists(1). Prim Care Update Ob Gyns, 8(1):31-35

4. Driskell, J.A., Kim, Y.N., Goebel, K.J. (2005). Few differences found in the typical eating and physical activity habits of lower-level and upper level university students. Journal of the American Dietetic Association, 105(5), 798-801.

5. Eisenberg, D., Nicklett, E.J., Roeder, K., Kirz, N.E. (2011). Eating disorder symptoms among college students: prevalence, persistence, correlates, and treatment-seeking. J Am Coll Health.;59(8):700-7.

6. Garner, D.M., Olmsted, M.P., Bohr, Y., Garfinkel, P.E. (1982). The Eating Attitudes Test:psychometric features and clinical correlates. Psychol Med, 12(4):871-878.

7. Garner, D.M., Rosen, L.W., Barry, D. (1998). Eating disorders among athletes Research and recommendations. Child Adolesc Psychiatr Clin N Am. Oct;7(4):839-57.

8. Gladović, B. (1999). Nezadovoljstvo vlastitim tjelesnim izgledom kod studenata i studentica. Diplomski rad. Rijeka: Filozofski fakultet, Sveučilište u Rijeci.

9. Hoerr, S.L., Bokram, R., Lugo, B., Bivins, T., Keast, D.R. (2002). Risk for disordered eating relates to both gender and ethnicity for college students. J Am Coll Nutr.21(4):307-14.

10. Lavender, J.M., De Young, K.P., Anderson, D.A. (2010). Eating Disorder Examination Questionnaire (EDE-Q): norms for undergraduate men. Eat Behav.11(2):119-21.

11. Lee, K. J., Dabrowski, K., Blom, J.H., Bai, S. C., Stromberg, P. C. (2002). A mixture of cottonseed meal, soybean meal and animal byproduct mixture as a fish meal substitute: growth and tissue gossypol enantiomer in juvenile rainbow trout (Oncorhynchus mykiss). J.Anim. Physiol. Anim. Nutr., 86 (7-8): 201-13.

12. Lepage, M.L., Crowther, J.H. (2010). The effects of exercise on body satisfaction and affect. Body Image. Mar;7(2):124-30. doi: 10.1016/j.bodyim.2009.12.002. Epub 2010 Feb 12. PMID: 20153709.

13. Makino, M., Tsuboi, K., Dennerstein, L. (2004). Prevalence of eating disorders: a comparison of Western and Non-Western Countries. Medscape Gen Med, 6(3):49.

14. Mintz, L.B., O Halloran, M.S. (2000). The Eating Attitudes Test: validation with DSM-IV eating disorder criteria. J Pers Assess. Jun;74(3):489-503.

15. Morris, K.D.V., Parra, G.R., Stender, S.R.S. (2011). Eating attitudes and behaviours among female college students. Jnl of college counseling, 14: 21-23. doi: 10.1002/j.2161-1882.2011.tb00061.x

16. Nelson, W.L., Hughes, H.M., Katz, B., Searight, R. (1999). Anorexic eating attitudes and behaviors of male and female college students. Adolescence, 34, 621-633.

17. Rukavina, T. (2002). Internalizacija ideala tjelesnoga izgleda, nezadovoljstvo tijelom i simptomi poremećaja hranjenja kod adolescenata. Diplomski rad. Rijeka: Filozofski fakultet, Sveučilište u Rijeci.

18. Schmidt, U. (2003). Aetiology of eating disorders in the 21(st) century: new answers to old questions. Eur Child Adolesc Psychiatry. 12 Suppl 1:130-7.

19. Sepulveda, A.R., Carrobles, J.A., Gandarillas, A.M. (2008). Gender, school and academic year differences among Spanish university students at high-risk for developing an eating disorder: an epidemiologic study. BMC Public Health.8:102.

20. Smith, S. P. (2005). Beyond games, gadgets, and gimmicks: Differentiating instruction across domains in physical education. Journal of Physical Education, Recreation \& Dance, 76(8), 38-45.

21. Stephens, N.M., Schumaker, J.F., Sibiya, T.E. (1999). Eating Disorders and Dieting Behavior Among Australian and Swazi University Students. The Journal of Social Psychology 139:2, pages 153-158.

22. Trivunčić, S. (1998.). Validacija inventara poremećaja hranjenja i Skale stavova prema hranjenju. Diplomski rad. Filozofski fakultet. Sveučilište u Rijeci, Rijeka.

23. Vohs, K.D., Heatherton, T.F., Herrin, M. (2001). Disordered eating and the transition to college: a prospective study. Int J Eat Disord. 29(3):280-8.

24. White, S., Reynolds-Malear, J.B., Cordero, E. (2011). Disordered eating and the use of unhealthy weight control methods in college students: 1995, 2002, and 2008. Eat Disord.19(4):323-34.

\section{Correspondence to:}

Amra Nožinović Mujanović,

Faculty of Physical Education and Sport, University of Tuzla, Bosnia and Herzegovina

E-mail: amra.nozinovic@untz.ba 